\title{
Globalization, Localization, Education and Technology
}

\author{
N. Krishnaswamy ${ }^{1,2^{*}}$ \\ 'Professor, Central Institute of English and Foreign Languages, \\ Hyderabad, A.P., India; krishnaswamy31@hotmail.com \\ 2Emeritus Professor, JVB University, Ladnun, Rajasthan, India
}

\begin{abstract}
Globalization is not something new; there were several earlier waves of globalization - religionization, colonization, imperialization and contemporary globalization. Hyperglobalizers argue for the present wave of globalization, localizers argue for 'reverse globalization' and 'hetrogenization' and a third group advocates 'glocalization'. What is called globalization is nothing but 'economic globalization' for a select few and 'virtual globalization' for the tech-savvy technocrats. Yet, there is no ideological globalization' for which we need to think of strategies for promoting inclusive glocalization. To bring this into fruition, the focus should be on education and judicious use of technology. Furthermore, globalization is threatening the very existence of local culture and languages and hence, the twin objectives, modernization without Westernization, must be built into our educational system. In the field of education, this necessitates the production of local materials without ignoring the global trends which should be our response to the perils of the present-day globalization and for initiating 'inclusive globalization'.
\end{abstract}

Keywords: Glocalization, Hetrogenization, Hyperglobalizers, Inclusive Glocalization, Posthuman Condition, Religionization, Rurban, Virtual Globalization

\section{Introduction}

Let me start with a story attributed to Lord Mahavira- the elephant and the six blind persons. Fredric Jameson [1], the culture critic, points out that globalization has become the modern or postmodern version of the proverbial elephant described by its blind observers in many different ways. Each one has a different interpretation'; though each is partly in the right, all are in the wrong!

What is globalization? The only thing that is clear is it is different from internationalization. 'Internationalization' means 'involving more than one nation'. Hindi is an international language since it is spoken in more than one nation; so is Chinese or Spanish; but, they are not global. Global means throughout the world - from China to Peru, from the Arctic to the Antarctic, from New Zealand to Iceland.

In simple terms, globalization refers to some driving forces that are shaping new forms of interconnections and flows among nations, economies, cultures, languages, and technologies. Globalization is a process and the result is globality.

\subsection{Globalization is not Something New; There were Several Earlier Waves of Globalization}

\subsubsection{Religionization}

The first one was religionization. This refers to the spread of Christianity, Islam, Hinduism, and Buddhism, resulting in

\footnotetext{
${ }^{*}$ Author for correspondence
} 
some form of globalization. Every wave had its upsides and flipsides/ advantages and disadvantages. Religionization came with its accompanying waves of culture and language; it was a package deal. Religionization gave us different philosophies about God, human beings, reality, etc. Vedantic, Biblical, Islamic, Buddhist, and Jainist points of view. What is interesting is the cultural appropriation that took place with every wave. For instance, when China imported Buddhism, it was the adoption not merely of a religion but of Indian cultures via religion. Ancient Indian civilization had no other way of disseminating its cultures to other parts of Asia than through religion. If we examine the Buddhist doctrines in China, we will find abundant evidence of Indian cultural elements. These elements are not limited to Buddhism, inasmuch as Buddhism itself is influenced by other religions of ancient India: particularly, Brahmanism, Mimamsa, Naya, Carvaka, and Jainism and it is clear that key concepts like dharma, atman, and vimoksa and a host of other ideas are not confined to Buddhism, but are found in Indian civilization as a whole. On the other hand, after Buddhism and its accompanying Indian cultures had gained a foothold in China, it got eventually localized as it happened with Zen, a localized Buddhist denomination. Thus, the introduction of Indian cultures enriched Chinese civilization, without making it any less Chinese in character. Similarly, Confucianism and Taoism, though influenced by Buddhism, kept their integrity as Confucianism and Taoism.

The Indian subcontinent, comprising what are now called India, Pakistan, and Bangladesh, has absorbed several 'waves' in the past and, with every wave some cultural appropriation took place. Actually in India, some form of mini- globalization with the effect of localization started much earlier with Aryanization, Mughalization, etc.; the Aryans and the Islamic invaders became settlers. The Aryans came with their Vedic culture, Sanatana Dharma, and the Sanskrit language and the long process of Aryanization of the subcontinent took place. Many Sanskrit words like 'kavya', 'dharma', 'gyan', 'dhan', 'daya, 'mukti', 'karunya' and a host of Sanskrit words entered even the Dravidian group. Then came the Persians and Greeks and one can find Persian and Greek influence in the art, architecture, and languages of the subcontinent. Reports by some Arab merchants of the fabulous wealth of India brought the Arabs to the frontiers of India. The int eraction had its effects both on India and on Muslim culture. The Muslims contributed their share of layers to the cultural heritage of India. During the Mughal period Persian was the language of the court and Arabic was the language of their religion, Islam. As a result of their interaction with the language of India a new linguistic entity, called Urdu, was born, adding a new layer to the rich linguistic heritage of India. The word "Urdu" itself is Turkish, meaning 'army' or 'camp'. The Urdu language symbolizes a linguistic process of synthesization by which the invaders willingly mixed their own language in favour of the local speech. All the elements in mathematics, astronomy, medicine, chemistry, and even literature and philosophy got synthesized. Words like 'sardar', 'malik', 'kushi', 'diwan'. 'Dharga,' 'namaas', 'raasta', 'dhukaan', 'zamindar', 'zilla', etc. must have come from Persian and Arabic through Urdu. Some words like 'imaam', 'saitan'. 'munshi', 'bismillah', 'kitab', amir', 'garib' etc. came via Arabic; even the word 'coffee' came from Arabic. Since India is a multi-linguistic area, most of these words got localized according to the flavour of the local language. Thus, a lot of acculturation took place even before the advent of the second wave of globalization.

At the same time, the growth of knowledge also resulted in various conflicts like the war of Crusades, persecutions, forced conversions, religious fundamentalism, jihads, etc.

\subsubsection{Colonization}

Then came colonization backed by industrialization. The real form of colonization started after 1500 when two European powers, Spain and Portugal, started exploring trade- routs to India and China to tap their resources. Then came France and England and laid the foundation for European empires for modern global trade and new systems of production that immensely benefitted people across Europe. This wave too, like the previous one, resulted in advantages as well as disadvantages. India got the English Language and appropriated it as another language of India, called Inglish ( the English of Indians with its own verities like Hinglish, Banglish, Tamglish, etc.), the railways and the postal system, and got industrialized but, at the same time, as we all know, there was huge exploitation, destruction, plundering, and humiliation. Industrialization helped colonization in a big way. In addition to the material wealth, the Europeans discovered Sanskrit, which led to the modern discipline called linguistics. Many Indian words entered the English language; words like shanti, yoga, guru, curry, rajah, coolie, bungalow, pandit, , juggernaut, jungle, mantra, avatar, maya, etc. (the latest being jugad from Punjabi, meaning improvisation)are commonly used even in international English A lot of other ideas also entered Europe through Persian and Arabic. As Bernard Cohn notes: 'The conquest of India was the conquest of Knowledge' [2]. 


\subsubsection{Imperialization}

After the two World Wars, particularly after 1945, came imperialization. The rivalry between the USA and the erstwhile USSR divided the world into two camps. The League of Nations and later the UNO came into existence. Later the USSR collapsed. Many colonies became free. Despite all these developments, new forms of imperialism emerged. The USA assumed the role of a global policeman; the IMF (International Monetary Fund), the World Bank, the US Dollar - all became globally powerful. Western values, Western capital, Western institutions, Western technology-all resulted in Westernization, though projected as Modernization. There was global hegemony and the world became not only more and more interdependent but also dependent on the USA.

\subsubsection{Contemporary Globalization}

Now, the current wave of contemporary globalization is actually a child of the two earlier forms of globalizationcolonization and imperialization, and heavily supported by technology and IT- a postmodern avatar of industrialization. It is a giant wave with many tidal waves; it is a tsunami.

Again, it has advantages and disadvantages. The world, as some say, has become 'a global village'; information technology has made the world a barrierless planet- no borders, no visas, no foreign exchange; one click of the mouse can take us anywhere. Loads of information is available on your palm- a great advantage indeed. But, one can see distinctly new forms of colonialism and imperialism emerging: cultural colonialism, economic imperialism, and linguistic genocide.

One group, called hyperglobalizers, argues in favour of the present wave of globalization. They say that the present wave is bringing about our long cherished dream of 'one world, 'one language', and 'one economy'. They point out that the dream is going to be realized as a result of modern technology, exchange of ideas, and more contacts; economic globalization and global job opportunities are the steps towards that goal. They further say the 'cultural homogenization' is good and all differences and conflicts will disappear with the shrinking space, time, and barriers. We can see that the present form of globalization is actually 'McDonaldization', 'Cocacolonization, and 'Americanization' with MTV, Hollywood, KFCs, Pizza Huts, faded jeans, 'dangerously low' low hip jeans, and fast food. It has already resulted in 'cultural imperialism' and 'linguistic genocide' killing all diversity in culture and language. Many languages have disappeared from the face of the planet and several local

Vol 1(2) | July-December 2014 | customs, traditions, food habits, dress patterns are fast disappearing.

The other group, called localizers, opposes the present form of globalization argues that actually the world is getting more and more localized and getting divided into more classes- the rich and the poor, the haves and the have-nots, billionaires and beggars, the computer literates and the computer illiterates, and so on; moreover, the present form of globalization, according to them, destroys diversity- a fundamental principle in nature, ecology, human nature, culture, and language; it kills variety- the spice of life. According to them, homogenization aims at uniformity and not unity.

This group also argues that only 'reverse globalization', meaning that non-Western countries influencing developments in the West, will result from this form of globalization as it can be seen in more forms of religious fundamentalism, ISIS in Iraq, Al-Jazera, Taliban, Al-Qaida, Ayodya, and several 'senas' emerging. So, they point out that 'hetrogenization' is unavoidable.

A third group advocates 'glocalization' - a combination of the global and the local, a kind of 'hybridity'; it will be a unified global with local identities. 'Think global but act local' is their slogan- a fusion as you see in music and art, these days. They say this is inevitable and give examples of McDonald, the American fast food giant, offering 'panneer pizzas', ' baingan pizzas' in India, Halal food in Islamic countries, thus even multinational changing according to the local needs. This group argues that both homogenization and hetrogenization are taking place at the same time, resulting in creative and chaotic tension and 'glocalization'. Adopting and adapting will in many ways protect pluralism, more tolerance, and encourage people to live in several cultures at the same time thus aiding globalization too. Indians have been doing this for centuries and live with several identities. Take for example, Mr. X the case of a Brahmin by birth, who belongs to the upper middle class in terms of socio-economic status, recites 'slokas' in the morning and performs the 'puja' all in Sanskrit, goes to a university where he teaches romantic poetry and Shakespeare in English ( In private conversation, he says all English literature is full of impurity and immorality and glorifies only the Ramayan and the Mahabharat!), goes to a local club where he drinks only imported whisky, uses only Gujarati at home and talks to his friends in Hindi, declares that he is a Hindu fundamentalist, goes to his family doctor, a Christian, and takes his child whenever the child is ill to a dargah where a Muslim saint does faith-healing; he always says he is a Gujarati and never says he is a Gujatati-Indian but his 
passport says he is an Indian! Such is the 'multiple identity' in the Indian context.

There are others like Amartya Sen who argue for 'inclusive globalization' that will include all sections of the society in the process of globalization in order to bring about a balanced society where 'welfare economics' will be the guiding principle and the benefits of globalization will be distributed equitably. So, it is not globalization or no globalization but what kind of globalization which matters.

The debate goes on and the proverbial elephant keeps growing!

\section{In Practice}

The ground reality is the Western American Metro-culturethe power of technology and money- all swallowing and gulping up the rest of the world. The world, as they say, has become Windows-centric and Apple-crazy! In India, what we see in a globalized India and the other India: the India of IT parks, MNCs, new corporate hubs like Gurgaon, Electronic Cities, Cyberabads, corporate executives, and white-collar workers; the Other India, Bharat, as we used to call it, is the land of small farmers whose land is usurped by the corporate, of tribals clinging to the forests that are fast disappearing, the landless Dalits living in the shadow of upper caste atrocities, women facing constant sexual harassment, the urban poor and the shivering construction workers living next to sky-rise buildings and gated-communities- it is another global phenomenon. Agricultural land is shrinking and IT companies and MNCs are buying up all the agricultural land; farmers either migrate or commit suicide; the number of urban poor is increasing; corruption from cradle to grave, criminalization in the name of politics, plastic pollution, health problems, etc. Even rural areas are facing all the problems of the metros.

What is called globalization is nothing but 'economic globalization' for a select few and 'virtual globalization' for the tech-savvy technocrats. There is no sign of 'political globalization' or 'ideological globalization' and the dream of 'one world' coming true. Do you think nations will give up their borders or identities? Will the USA or China or Pakistan or India will ever give up even an inch of land in a situation where territorial expansion and fighting over even barren lands is the trend? Even small countries are floating their own airlines with their brand-name! Nations will never give up their geographical and political identities because of power and self-interests and the age old concept of patriotism deeply rooted in our minds. Real globalization will always remain a dream. Maybe, under a posthuman condition, if and when it happens, 'real' globalization will take place- certainly, not with the present state of human nature $[3,4,5]$.

At the cultural level, what we witness is the emergence of a 'hybrid' culture; this hybrid culture started in the metros but fast spreading to all other parts of the country, 'rurban' as well as rural. When we try to implant Western values learnt through the music we hear, the movies and books we read, and the television we watch. In the Indian context, there are bound to be anomalies. Unfortunately, this hybrid culture has abandoned all that was good, valuable and time-tested in the older systems of India and has taken all the undesirable and 'unwanted' elements from the West, only some of the outer forms. For instance, the jeans and T-shirt may be convenient for those who travel and work but fast food, pizza and burgers are certainly not good for health; the jeans wearing population dirties public places without any sense of shame; they have not taken any one of the desirable, 'inner' aspects of social discipline from the West, like forming queues or the road discipline; the outwardly Westernized crowd throws garbage everywhere without any compunction. The old values like respect for nature or fellow human beings are lost; no compassion for fellow beings or elders; only materialism and selfishness are found in the hybrid culture that is emerging. So, it is not a question of just 'hybrid culture' that is unavoidable in a globalized world but what kind of hybrid culture that is evolving. We do not want to blindly follow the West but go our own way, adjusting some of the Western ideas to our own needs-spiritual, moral, and cultural, economic circumstances, and based on our own heritage. Acceptance of Western science and technology does not necessarily mean acceptance of Western cultural values, beliefs, and lifestyles. If that happens, the self-identity will be destroyed.

How to counter the onslaught of the West on the Rest and at the same time bring about what I would like to call 'Inclusive Glocalization' with proper safe guards for local languages and cultures, and taking into consideration the interests and welfare of all sections of the population , without ignoring English as a professional language. "Inclusive glocalization' must include not only all human beings- the rich and the poor, the whites, blacks and the browns- but also all living things- animals, trees and plantsso that nature and ecology are protected in addition to all kinds of culture and languages. Only then the development can be called 'global' along with 'local'. For this, we need to evolve globally an inter-cultural pedagogy that will be effective in multi-cultural contexts. We need to think of strategies for promoting inclusive glocalization, which is not an easy thing to do. 
So, the focus should be on education and judicious use of technology in the globalized world; education is the place where actual forms of social and political consequences are defined and contested, values and beliefs are constructed, and self-identity is created.

\section{Education, Technology in a Globalized World, and India's Response}

Interestingly, Gandhi and Nehru, the two leaders who struggled together for three decades to free their country from foreign domination, present two different but fundamentally and dramatically opposed encounters with foreign culture in their cultural identity. 'I cannot, 'Nehru declares, 'get rid of either the past inheritance or my recent acquisitions. They are both part of me, and, though they help me in both the East and the West, they also create in me a feeling of spiritual loneliness not only in public activities but in life itself' [6]. Spiritual loneliness, cultural in-betweenness, and psychological ambivalence, resulting from cultural and educational hybridity, made him say, 'In my own country I have an exile's feeling' [6]; it created a cultural limbo in him- neither here nor there. Gandhi, on the other hand, had no cultural ambivalence in spite of his foreign encounters. He knew where his roots were; his encounters with native and foreign cultures produced in him an enriched and enlightened cultural persona. He aptly declared. 'I do not want my house to be walled in on all sides and my windows to be stuffed. I want the cultures of all lands to be blown about my house as freely as possible. But I refuse to be blown off my feet by any. I refuse to live in other people's houses as an interloper, a beggar or a slave' [7]. 'Nothing can be further from my thought, he observed, 'than that we should become exclusive or erect barriers. But I do respectfully contend that an appreciation of other cultures can fitly follow, never precede, an appreciation and assimilation of our own' [8]. Gandhi rejected cultural isolationism and freely acknowledged his debt to Western culture in his own identity formation. It is this Gandhian view with its twin pillars of rootedness and openness that offers a strong foundation for the planning and construction of the fusion of the global and the local in education, self-identity, and cultural consciousness, particularly in a globalized world. Gandhi believed that education was merely an instrument and 'an instrument may be well - used or abused. The same instrument that may be used to cure a patient may be used to take his life, and so may knowledge of letters. We daily observe that many men abuse it and very few make use of it.... [9]. This is true not only of education but also technology and the application of technology in education.

J. Krishnamurti, the well-known thinker, says, 'Our present education is geared to industrialization and war, its principal aim being to develop efficiency; and we are caught in this machine of ruthless competition and mutual destruction. If education leads to war, if it teaches us to destroy and be destroyed, has it not utterly failed?...... The function of education is to create human beings who are integrated and therefore intelligent. We may take degrees and be mechanically efficient without being intelligent. Intelligence is not mere information; it is not derived from books, nor does it consist of clever self-defensive responses and aggressive assertions. One who has not studied may be more intelligent than the learned. We have made examinations and degrees the criterion of intelligence and have developed cunning minds that avoid vital human issues. Intelligence is the capacity to perceive the essential, the is; and to awaken this capacity, in oneself and in others, is education' [10].

At present, our educational system is completely market-driven; degrees are mass produced and even manufactured; education has become a money-making industry; somehow get a degree, somehow get a job, and somehow make money has become the goal of education. Even in the IT industry, where there is more money and more pay, there are many respectable terms like 'project', 'outsourcing', 'transcription', etc. to employ, what was known as 'slave trade' in olden days, 'cyber coolies' in the 'sweat shops' in countries where cheap labour is available; even skilled employees accept the position willingly even though they get only a part of what an employee gets in the developed world. Economic globalization and materialism driven by modern technology has engulfed the world. We can see this in every walk of life; changing life styles, smart homes, smart phones, smart kitchen and smart appliances, smart boys and girls (sometimes too smart!), on line shopping and banking, online chatting, healthcare and medicine, robots doing even household chores, genetically modified food items, e-bhakti and e-prasad, even prayers and burial get 'outsourced'- you name it and the application of technology is there! But, moderation must be the mantra. Education too is not left out from this all pervasive and omnipresent phenomenon. Education is undergoing a phenomenal metamorphism under the influence of technology. Many online courses, online universities have started giving courses; any lecture given by a professor in MIT or Harvard or Oxford can be recorded in any part of the world and replayed according 
to the convenience of learners. This has freed classrooms from the limitations of time and space. We know of Khan Academy, a non-profit educational organization created in 2006 by educator Mr. Khan, to provide "a free, world-class education for anyone, anywhere." Its website features thousands of educational resources, including a personalized learning dashboard, over 100,000 practice problems, and over 6,000 micro lectures on You-tube and videotutorials, teaching mathematics, history, healthcare, medicine, finance, physics, chemistry, biology, astronomy, cosmology, American civics, art history, economics, and computer science. All resources are available for free to anyone around the world. By 2013, they were used by about 10 million students per month. Khan Academy's micro lectures have been watched over 440 million times. In India too, along with the TV, many companies like Pearson Education, Educomp, PurpleLeap, Ecole Solutions, WIZIQ education online, and many others are offering innovative and cost-effective programs to empower educational institutions; but they are yet to take off in a big way though there is a lot of potential for even satellite enabled digital classrooms, mentoring and coaching, arranging guest lectures, case study discussions, internships and projects via online. This can reduce the cost and make use of the best talent in the country. Some educational institutions did try with language labs and communication labs but the right kind of software suitable for Indian learners is not available. We have the talent and know-how. Today, particularly in the urban areas, the new generation called Gen $y / z$, have become digital learners or e-learners with a different lingo; they expect the teacher to understand their lingo and expect everything in the digital format; they do not want books and photo-copying. The learners are more active online than in the class; they are hooked to the social media all the time. They want classrooms on the social media like Facebook and Twitter so that they can log on from anywhere and learn; they expect lessons even on the mobile phones and in their language of texting. They want more interesting and challenging ways of learning like quizzes and puzzles, case studies, projects, problems, and seminars and discussions, and not conventional lectures that are boring and result in passive listening. They want teachers to understand and motivate them, allow them to explore their talent, and get practical and prepare for the real world of big careers. Teachers are not yet ready to meet their aspirations. Teachers and traditional scholars and administrators say that this new generation is interested only in I and E (i.e. I, Me, and Myself and Electronic gadgets) and the result is impatience, irritability, lack of concentration, and the desire for instant gratification.
That is why a book entitled 'Why Do You Need a Teacher When There is Google?' has appeared; but the writer does not realize that Google cannot cry with me and console me when I do not perform well or jump with joy and hug me when I excel in my performance; there is a need for human touch but it is fast disappearing under the influence of technology. Machines must be only extensions of human potential and not the substitutes for human beings. With appropriate software, technology in education can certainly complement even the most competent teacher; it will be of immense help to the average and below average teacher; but technology can never replace the human factor in education. There is a generation gap even in the urban areas in the styles of learning; the rural areas are not yet ready to embrace the digital revolution. Maybe, when this new generation of digital learners takes charge of education, things might change without killing the human element; we can only hope for it.

But, there are some peculiar problems in India. India is the world's largest democracy; India is not one but many; Gulam Mohammed Sheik says, 'Living in India means living simultaneously in several cultures and times' [11]. India is a multi-lingual, multi-cultural, multireligious, multiregional, and multi-ethnic phenomenon with democracy as its ideology. The complex cultural osmosis has been described differently by others as 'segmented identities' [12], 'fluid identity' [13], 'mosaic', 'salad bowl arrangement', etc. These 'modules' have been developed over centuries as part of the evolution of the Indian civilization. India was never and will never be 'a melting pot'! Apart from the several divisions of caste, class, religion, rural-urban, the haves and have-nots, there is also the important division between the literate and the illiterate and the computer literate and the computer illiterate. The constitution guarantees a right to education to the total population of about 1.3 billion people, resulting in a conflict between universal education and quality education. According to a recent guestimate, there are about 315 million students in India, which is about the total population of the USA and the teacher population in India equals the total population of some small countries like Switzerland or Sweden or Singapore. With not much connectivity and with other problems like poverty, malnutrition and other problems of day-to-day existence, imparting education to all sections of people is a formidable task. At the same time, we have to impart the right kind of education to all, taking care of the local conditions to preserve local culture and self identities. An educational system, obviously, should meet the aspirations of the people and impart universal education and at the same time 
change the society; education must be an instrument of social change and impart 'true' education and not pseudoeducation. True education must promote self-identity and self-respect and be rooted in the local culture in order to do it. But, with about 23 official (22+ English as the associate official language) languages and about 33 languages spoken by more than one lakh people, varying cultures in a vast area scattered in the urban and rural areas, education being on the concurrent list (shared between the States and the Centre), with the additional problem of autonomy of educational institutions and minority institutions with special privileges, and with all the party politics, it becomes too complicated for the human mind to comprehend.

\section{Let A Thousand Flowers Bloom}

Diversity is the law of nature outside in the environment as well as in human nature; there is no uniformity but there is unity and any attempt to impose uniformity will be disastrous. Globalization is threatening the very existence of local culture and languages. We cannot uproot ourselves and become perpetual immigrants or nomads in the name of globalization or Westernization. In other words, the twin objectives, modernization without Westernization, must be built into our educational system. It is true that the global, national, local, social, and individual realities are all interconnected; we cannot live in a bubble. Globalization makes it possible for individuals and societies to derive useful and usable insights from various sources; using such a facility, individuals and communities can and should try to make sense of their own and other's cultures. After all, 'making sense of ourselves is what produces identity' [14]. Globalization and the internet has vastly increased the interactional opportunities among the various culture both within and outside one's own culture, thus opening up unlimited possibilities for one's own and the local communities' cultural growth. This is a welcome trend that will facilitate the shaping and reshaping of all in a synergic way. At the same time, we cannot ignore the local wisdom and indigenous knowledge systems as Science International points out, 'That traditional and local knowled ge systems as dynamic expressions of perceiving and understanding the world, can make and historically have made, a valuable contribution to science and technology, and there is a need to preserve, protect, research and promote this cultural heritage and empirical knowledge [15].

In the field of education, this necessitates the production of local materials- printed as well as electronic- without ignoring the global trends. If the materials are home-spun and not imported from outside, the teaching-learning process will be more relevant and effective. This may be called swaraj or self-reliance in education. Those who are familiar with the local culture, context, and learning styles are the right people to create learning materials suitable for their learners. If teachers are not considered foot-soldiers, who do what they are ordered to do by outside authorities, but facilitators and partners in the process of learning, they will also become more responsible and accountable; in addition, the process of training teachers through materials production will have a lasting effect since the material produced will be locally effective, taking into account the ground realities. Innovative materials of all kinds need to be generated, using all possible media- print, audio, video, multimedia, satellite, TV, CD Rom, animation, computer based, computer assisted, local internet/extranet, webbased, both in and out of classrooms, for all learners-adults, home makers, businesspeople, doctors, lawyers, politicians, marginalized sections of the population, etc. so that they can learn any subject, anytime, according to their level, pace and space, and ability. E-learning should not mean only electronic media and technology but 'Earnest, Essential, Educational learning for Everybody'. The materials are to be designed in such away to encourage self-reflection and self-learning to raise cultural consciousness with popular cultural themes like local values, family relationships, festivals, sports, music, food and fashion, etc. Though the themes are familiar, they make them understand unfamiliar dimensions and defamiliarize the familiar and that should be part of the instructional strategy. In addition, themes like 'Know your neighbour', 'Know thyself', and 'Know the world', etc. will also give a global perspective and contribute to dismantle cultural stereotypes. This is a formidable task indeed but it is worth attempting if done in the spirit of the freedom movement of the 1940s since it will usher in a 'second freedom movement' in education, not only for India but also for countries with similar problems. That should be our response to the perils of the present-day globalization and for initiating 'inclusive glocalization'.

Let's pave the way for a thousand flowers to bloom.

\section{Works Cited}

1. Jameson F. "Notes on Globalization and Philosophical Issues," In Jameson and M. Miyoshi (Eds.). The Cultures of Globalization, Durham, NC: Duke University Press, p. 54-77, 1998.

2. Cohn, Bernard S. Colonialism and Its Forms of Knowledge: The British in India. Princeton University Press, 3. 1996

3. Nichlos, Steve. "The Posthuman Manifesto", Games Monthly, 1988.

HuSS: International Journal of Research in Humanities and Social Sciences 
4. Dixon, Dougal. Man After Man: Anthropology of the Future, New York: St. MartinTs Press, 1990.

5. Pepperell, Robert. The Posthuman Condition- consciousness beyond the brain, Bristol, UK: Inrellect, 1995/2003.

6. Nehru, J. An Autobiography, New Delhi: Oxford University Press, 596, 1936/1980.

7. Gandhi M.K. An Autobiography, Or the Story of $M y$ Experiments with Truth, Ahmadabad: Navjivan Publishing House, 53, 1927/1997.

8. Gandhi M.K. "English Learning”, Young India, vol. 170, Sep $1,1921$.

9. Gandhi M.K. The Penguin Gandhi Reader, (ed.). R. Mukherjee New Delhi; Penguin Books, 1993.

10. Krishnamurti J. Education and the Significance of Life, Ojai, California: Krishnamurti Foundation of America, 1953/2000.

11. Sheikh, Gulam Mohammed. Quoted by Renuka Sawheny in http://www.guildindia.com/. August 7, 2012.

12. Thapar, Romila. Interpreting Early India. New Delhi: Oxford University Press. 1993.

13. Nandy, Ashis. 1983. The Psychology of Colonialism: Sex, Age, Ideology in British India. The Intimate Enemy: Loss and Recovery of Self under Colonialism. New Delhi: Oxford University Press, 1-64.

14. Spivak, Gayatri C. Outside in the Teaching Machine, New York: Routledge, 200, 1993.

15. Science International, September 1999, p.4.

\section{Other References}

1. Appadurai A. Modernity at Large: Cultural Dimensions of Globalization, Minneapolis, MN: Minnesota University Press, 1996.
2. Bhabha H.K. The Location of Culture, New York: Routledge, 1994.

3. Dharampal. The Beautiful Tree: Indigenous Indian education in the Eighteenth Century, New Delhi: Bibla Impex Private, 1983.

4. Haraway, Donna J. Simians, Cybrogs and Women: The Reinventing of Nature, New York: Routledge, 1990.

5. Hayles, Catherine N. How We Became Posthuman : Virtual Bodies in Cybernetics, Literature and Informatics: University of Chicago Press, 1999.

6. Krishnaswamy N. The Politics of Indians' English, New Delhi: Oxford University Press, 1998/2004.

7. Krishnaswamy N. The Story of English in India, New Delhi: Cambridge University Press, Foundation Books, 2006.

8. Krishnaswamy R. 2008. The Postcolonial and the Global. (Ed.), Revathi Krishnaswamy and John C. Hawley, Minneapolis: University of Minnesota Press, 2006.

9. Kumaravadivelu B. Cultural Globalization and Language Education, New Haven: Yale University Press, 2008.

10. Pennycook A.D. The Cultural Politics of English as an International Language, London: Longman, 1994.

11. Pennycook A.D. English and the Discourses of Colonialism, New York: Routledge, 1998.

12. Phillipson, Robert. Linguistic Imperialism, Oxford: Oxford University Press, 1992.

13. Rapatahana V., Bunce P. English Language as Hydra: Its Impacts on Non-English Language Cultures, Multilingual Matters, Bristol: 2012.

14. Steger M. Globalization; A Very short Introduction, Oxford: Oxford University Press, 2003.

15. Tomilson J. Globalization and Culture. Cambridge: Blackwell Publishers, 1999. 